\title{
BRANDING KERAJINAN DARI LIMBAH TEH RENDY HANDYCRAFT
}

\author{
Rinanda Purba \\ Prodi Desain Komunikasi Visual \\ Fakultas Seni dan Desain Universitas Potensi Utama Medan \\ Rinanda.purba.silangit@gmail.com
}

\begin{abstract}
ABSTRAK
Rendy Handycraft merupakan sanggar yang mengolah limbah bubuk teh menjadi kerajinan yang bernilai jual, menonjolkan cindramata yang khas yang diperuntukkan bagi semua usia, mulai dari anak-anak, remaja hingga dewasa, mulai dari celengan hingga plakat resmi antar institusi, dan semua proses yang dilakukan dalam pembuatan adalah murni handmade. Sebagai sebuah brand lokal Kota Medan yang memiliki keunikan tersendiri, Rendy Handycraft dirasa perlu untuk memiliki logo dan corporate identity sehingga dapat dikenal oleh masyarakat luas khususnya wisatawan dari luar Kota Medan yang akan menjadian produk-produk Rendy Handycraft sebagai cindramata. Metode perancangan yang akan digunakan yaitu melalui tiga tahap, diantaranya tahap pra-desain yaitu pengumpulan data yang dibutuhkan sebagai sumber ide dalam perancangan, tahap desan yaitu proses eksekusi konsep menjadi final desain yang nantinya akan digunakan, dan tahap pembakuan desain yang merupakan tahap untuk memberi standarisasi penggunaan hasil desain yang telah dibuat.
\end{abstract}

Kata Kunci: Logo, Rendy Handycraft, Medan

\begin{abstract}
Rendy Handycraft is a studio that processes wasted tea powder into a valuable craft, highlighting unique souvenirs for all ages, from children, teenagers to adults, from money box to official souvenir between institutions, and all processes carried out in The manufacture is pure handmade. As a local brand of Medan City that has its own uniqueness, Rendy Handycraft is considered necessary to have a logo and corporate identity so that it can be known by the wider community, especially tourists from outside the city of Medan who will be selling Rendy Handycraft products as souvenirs. The design method that will be used is through three stages, including the pre-design stage, namely the collection of data needed as a source of ideas in the design, the design stage, namely the process of executing the concept into the final design that will be used, and the standardization stage of the design which is a stage to provide standardization use of the design results that have been made.
\end{abstract}

Keywords: Logo, Rendy Handycraft, Medan 


\section{PENDAHULUAN}

Limbah adalah zat atau bahan buangan yang dihasilkan dari proses kegiatan manusia (Ign Suharto, 2011 :226). Limbah memiliki banyak jenis, diantaranya kotoran hewan, limbah tanaman, limbah rumah tangga, dan barang bekas. Penumpukan sampah/limbah dapat menyebabkan ketidak seimbangan kondisi lingkungan karna jumlah limbah yang melebihi batas kuantitas yang dapat ditoleransi oleh lingkungan, Sehingga dapat menyebabkan pencemaran. Hal ini akan berdampak buruk apabila tidak dilakukan penanganan yang tepat. Tidak hanya menyebabkan lingkungan yang kotor dan terkesan kumuh, tetapi limbah juga dapat menyebabkan bahaya keracunan termasuk sisa limbah rumah tangga seperti sisa ampas teh.

Ampas teh merupakan salah satu jenis limbah yang ekstraksinya bersifat mudah busuk sehinga dapat mencemari lingkungan. Salah satu pemanfaatan limbah ekstraksi teh adalah sebagai celengan limbah teh. Bahan dasar pembuatan kerajinan dari limbah bubuk teh yaitu sisa ampas teh yang telah dikeringkan kemudian ditabur ke media yang sebelumnya telah dioleskan lem putih sehingga material bubuk teh dapat merekat pada media.

Rendy Handycraft merupakan pengrajin yang bergerak dalam bidang kerajinan limbah bubuk teh yang ada di Kota Medan. Perancangan sebuah identitas merupakan sebuah hal yang sangat penting bagi sebuah usaha, karena identitas adalah hal yang sangat penting untuk menjaga pencitraan demi keberlangsungan perusahaan yang terkait pada eksistensi masyarakat, informasi perusahaan, promosi perusahaan dan persaingan dengan pengrajin lainnya.

Logo baru Rendy Handycraft mencitrakan pengrajin yang sadar akan lingkungan, peka terhadap pemanfaatan limbah, kreatif dan menginspirasi yang nantinya akan digunakan sebagai salah satu marketing tools dalam memasarkan produk kerajinan khas medan. Logo baru Rendy Handycraft diharapkan juga dapat menunjukkan bahwa Rendy Handycraft ramah lingkungan, alami, murah, bahan yang aman untuk anak-anak yang divisualisasikan secara simple, modern dan dinamis. Secara visual logo baru Rendy Handycraft merepresentasikan bentuk bangunan sanggar, daun teh, dan kerajinan tangan yang menampilkan brandname "Rendy Handycraft" sebagai logotype dan menggunakan warna hijau - coklat, merah dan orange sebagai alternatif.

\section{STUDI LITERATUR}

Beberapa tulisan yang dijadikan rujukan dalam penelitian ini adalah karya Rosella Julita yang berjudul "Perancangan Logo \& Corporate Identity Hotel Gowin Bali". Makalah ini berisikan tentang perancangan corporate identity dari Hotel Gowin. 


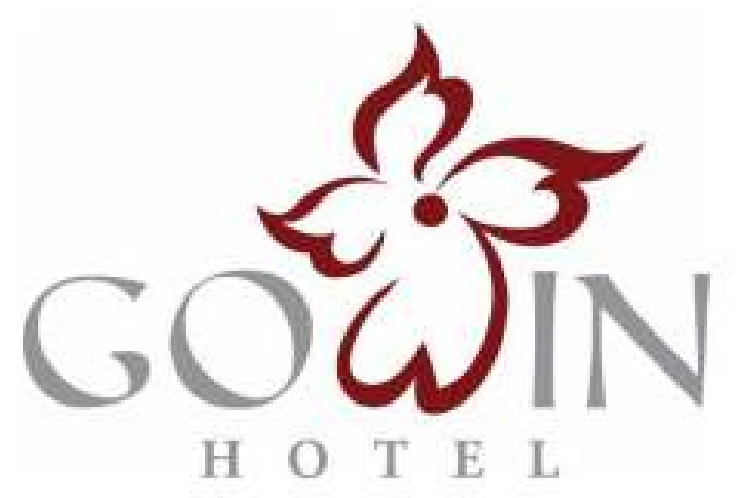

Gambar 1. Logo Hotel Gowin Bali

Logo ini memiliki 2 elemen, yaitu logo gram dan logo type, logo gram pada logo Hotel Gowin merupakan bentuk bunga kamboja yang memiliki metafor anggun, tradisional, dan lembut yang mewakili gadis Bali. Semetara logo type dari Logo Hotel Gowin Bali merupakan modifikasi dari Huruf Roman SD yang serifnya dihilangkan.

Selanjutnya tulisan dari Athika Dwi Wiji Utami yang berjudul "Perancangan Desain Logo LBH Sandhi Wafa \& Partners Counselor \& Attorneys At Law". Makalah ini berisikan tentang perancangan logo LBH Sandhi Wafa \& Partners Counselor \& Attorneys at Law. LBH Sandhi Wafa \& Partners Counselor \& Attorneys at Law yang berkantor di ruko Puri Indah RK 10 Cemengkalang Sidoarjo.

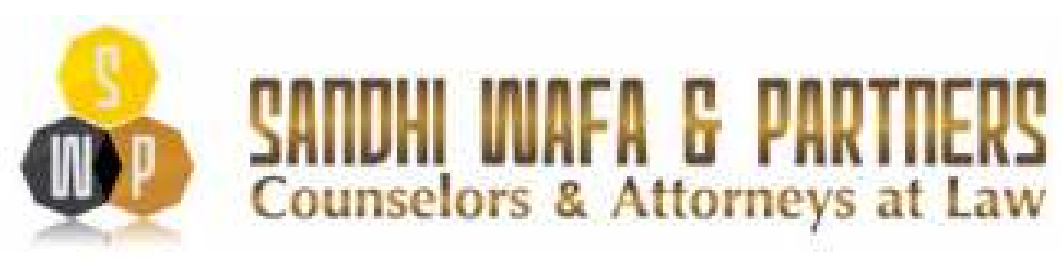

Gambar 2. Logo Sandhi Wafa \& Partners

Pada logo ini memiliki konsep penggunaan tipografi sebagai logo utama dengan mengambil akronim dari Sandhi Wafa \& Partners (SWP) yang dibungkus dengan frame segi delapan dan menggunakan warna hitam, kuning dan coklat yang berkesan elegan dan dinamis 


\section{PEMBAHASAN}

\section{III.1. Produk}

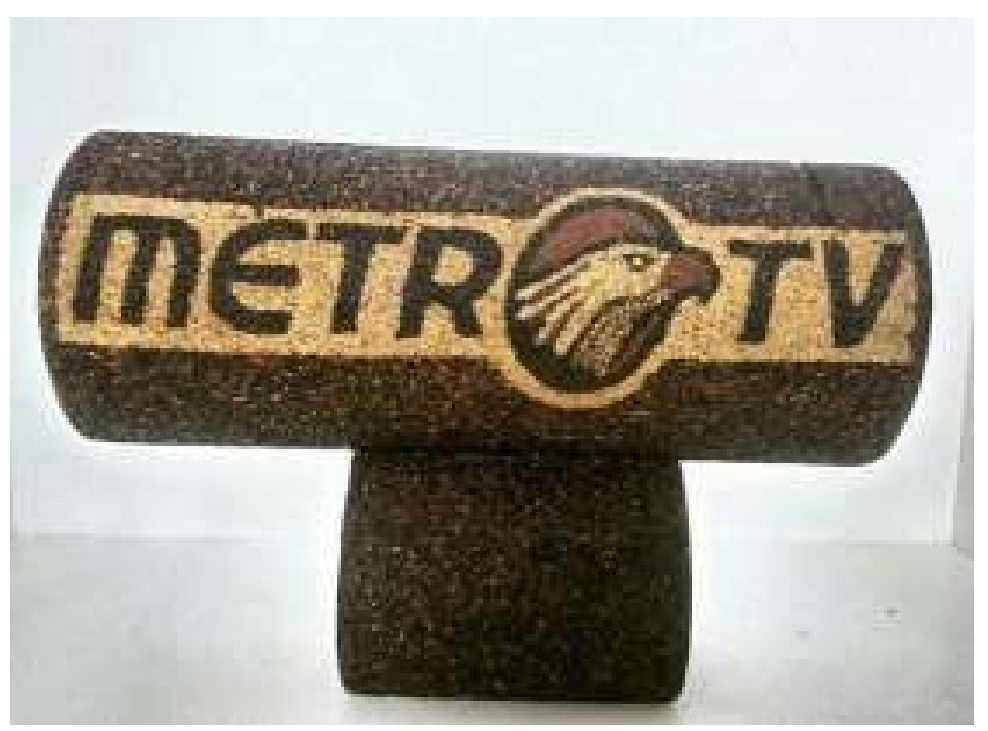

Gambar 3. Souvenir Metro TV

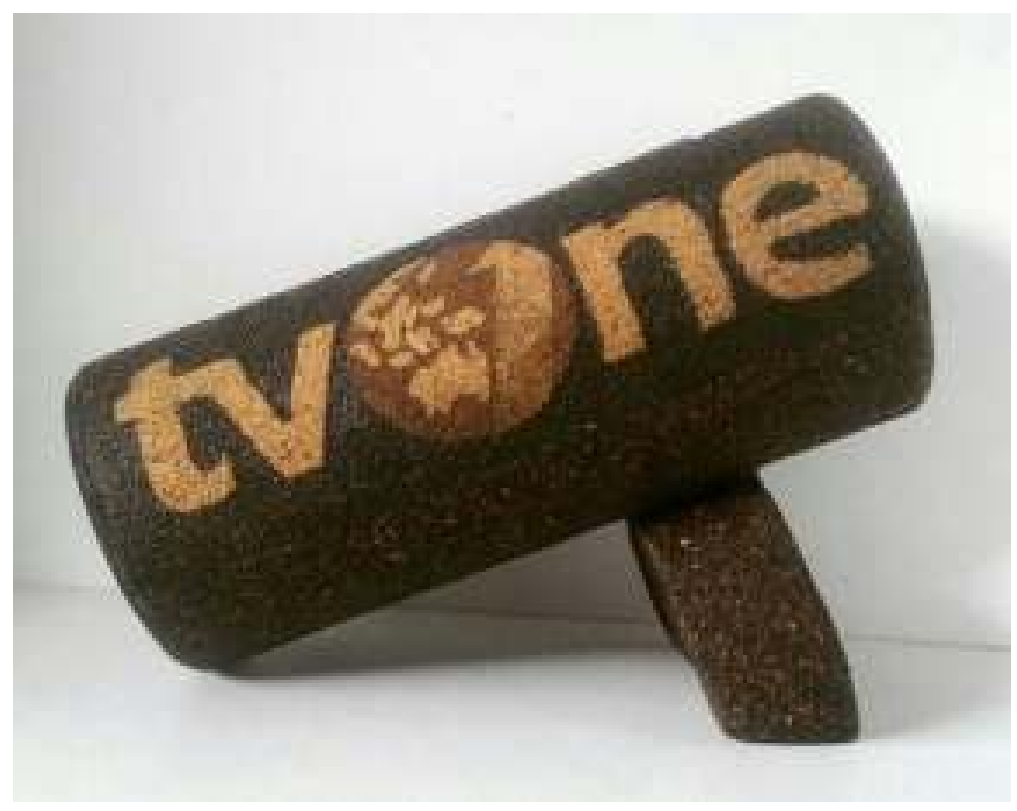

Gambar 4. Souvenir TV One 


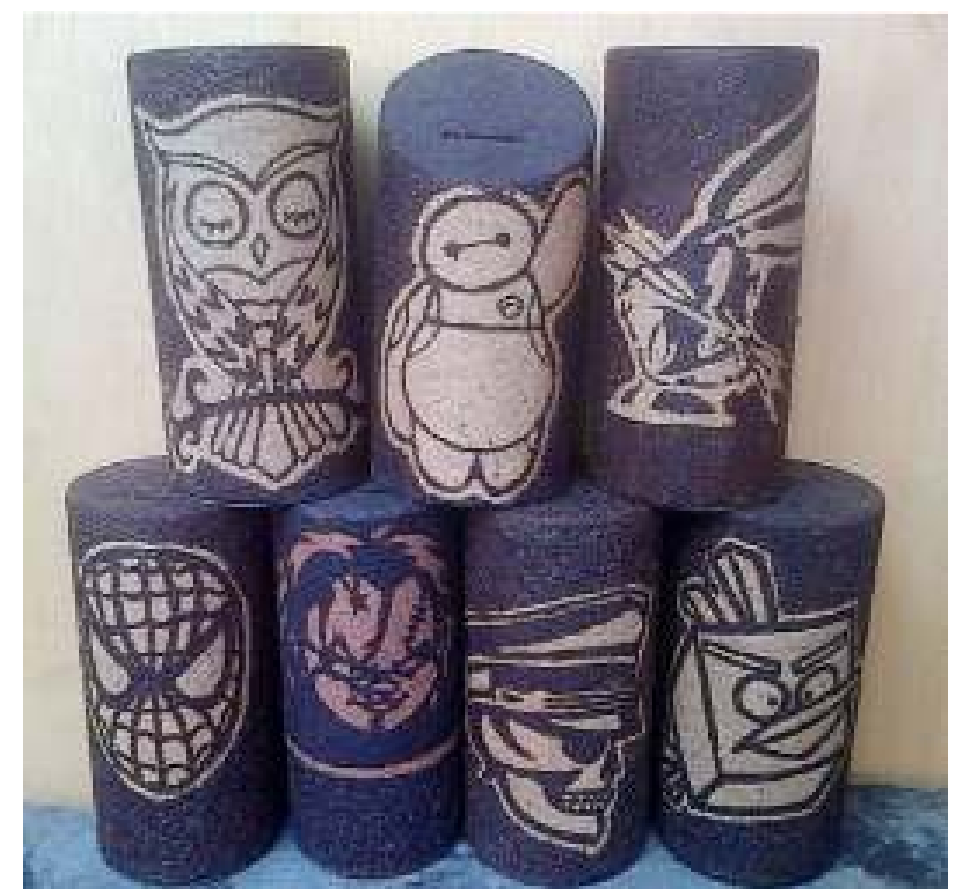

Gambar 5. Celengan

\section{III.2. Kerangka Perancangan}

Perancangan ini disusun melalui tiga tahapan kerja mulai dari tahap pradesain, desain, dan pembakuan.

a. Tahap Pradesain

Tahap Kaji Konsepsi yang menggali nilai, ruang lingkup usaha, jaringan komunikasi, leadership, dan ritual dikaji untuk memahami karakteristik budaya perusahaan serta menggali corporate image yang dikehendaki oleh manajemen. Langkah operasionalnya ditempuh melalui diskusi mendalam dengan para pimpinan perusahaan serta observasi, angket dan kaji literatur. Keluaran (output) dari kajian ini adalah terciptanya Konsep Logo.

b. Tahap Desain

Sketsa Logo, berangkat dari konsep desain, dirancang berbagai kemungkinan visualisasi berupa sketsa gagasan logo.

c. Tahap Pembakuan

1. Standarisasi bentuk (grid system, proporsi, skala).

2. Standarisasi warna.

3. Standarisasi huruf.

4. Standarisasi konfigurasi tata letak.

5. Standarisasi teknik produksi.

Selain hal yang bersifat teknis tersebut dalam guidance book juga akan diuraikan tentang:

1. Pengertian logo secara umum.

2. Arti dan makna logo.

3. Kebijakan penggunaan logo.

Aplikasi pada media mandatori corporate identity. 


\section{III.4. Rendy Handycraft}

Rendy Handycraft merupakan sanggar yang mengolah limbah bubuk teh menjadi kerajinan yang bernilai jual, menonjolkan cindramata yang khas yang diperuntukkan bagi semua usia, mulai dari anak-anak, remaja hingga dewasa, mulai dari celengan hingga plakat resmi antar institusi, dan semua proses yang dilakukan dalam pembuatan adalah murni handmade. Bahan dasar pembuatan celengan limbah teh berasal dari karton bekas gulungan kain dan limbah bubuk teh yang telah dikeringkan. Proses awal pembuatan celengan ini adalah dengan membuat sketsa menarik di karton gulungan. setelah itu, sketsa gambar di karton diberi lem agar gambar tersebut terlihat berwarna dengan limbah teh.

\section{III.5. Objek/Tema/Konten}

Objek yang akan dibranding adalah pengrajin celengan yang berbahan dasar limbah bubuk teh yang ramah lingkungan, bercitra bentuk fisik sanggar, daun teh, kerajinan tangan, dan alam. Objek akan divisualisasikan dapat terjangkau oleh semua kalangan dan akan divisualkan secara simple, modern dan dinamis.

\section{III.6. Target Market}

Target utama dalam perancangan ini adalah masyarakat, dimana didlam masyarakat tersebut target audience yang ditinjau adalah sebagai berikut:

\section{a. Demografis}

Usia 5 - 50 tahun

Terdiri dari:

Anak-anak

Remaja

Orang dewasa

Orang tua

Jenis kelamin: Laki-laki dan Perempuan

\section{b. Geografis}

Lokasi sasaran yang dituju dalam perancangan ini adalah Kota Medan.

\section{c. Psikografis}

secara psikografi, target audience yang dituju adalah:

Kelas sosial : semua golongan sosial

Gaya hidup : branded, konsumtif

\section{7. Kajian Konsep Logo}

a. Keyword

Tabel 1. Keyword Konsep Logo

\begin{tabular}{|ll|ll|ll|}
\hline \multicolumn{2}{|c|}{ SUBJEKTIF } & \multicolumn{2}{|c|}{ OBJEKTIF } & \multicolumn{2}{c|}{ VISUAL } \\
\hline 1. & Produk Kreatif & 1. & Ramah Lingkungan & 1. & Bangunan sanggar \\
\hline 2. & Stakeholder & 2. & Alami & 2. & Brandname: Rendy Handycraft \\
\hline 3. & Home Industri & 3. & Menginspirasi & 3. & Hijau \\
\hline
\end{tabular}




\begin{tabular}{|c|c|c|}
\hline \multirow{9}{*}{\begin{tabular}{|ll} 
4. & Marketing tools \\
5. & Nasionalis \\
\end{tabular}} & 4. Inovatif & 4. Coklat \\
\hline & 5. Bahan Aman & 5. Elipse \\
\hline & 6. Terjangkau & 6. Segitiga \\
\hline & 7. Mandiri & \\
\hline & 8. Passion & \\
\hline & 9. Terpercaya & \\
\hline & 10. Moderen & \\
\hline & 11. Dinamis & \\
\hline & 12. Simple & \\
\hline
\end{tabular}

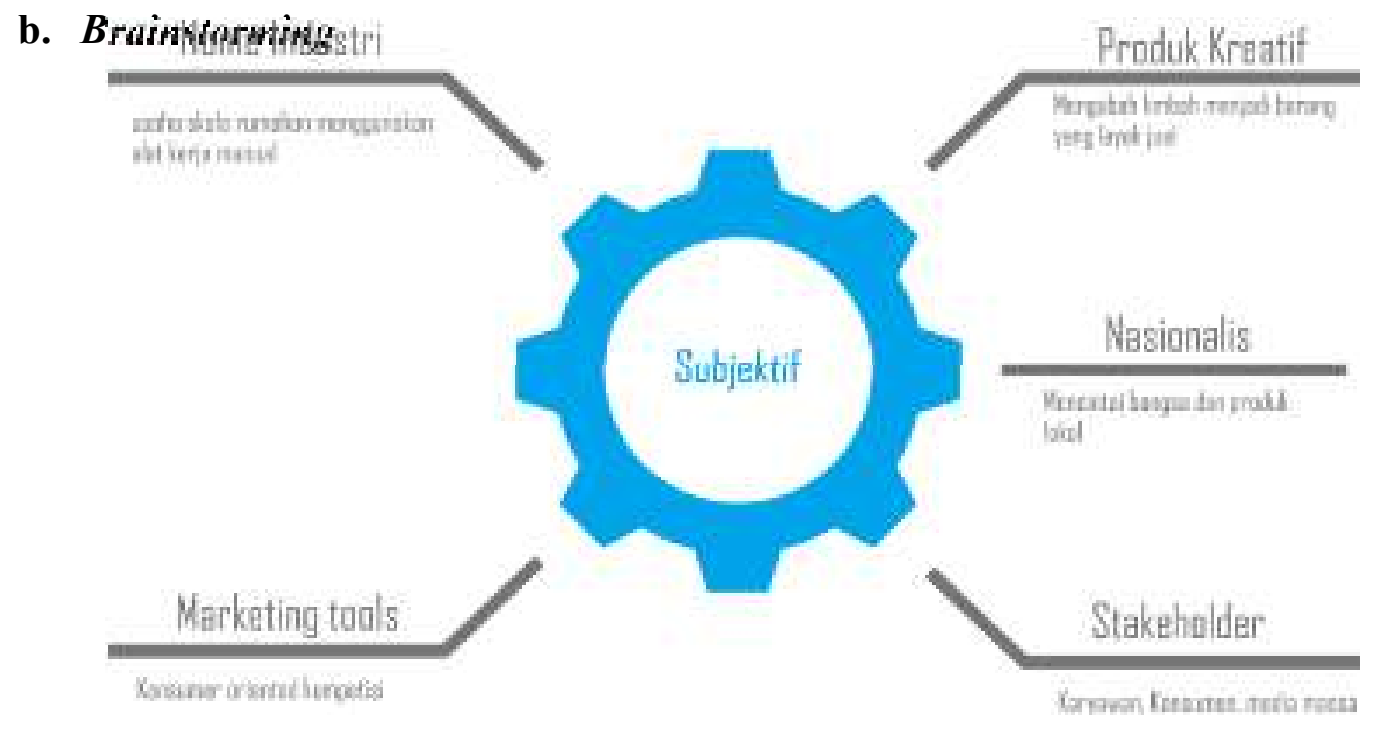

Gambar 6. Brainstorming yang bersifat subjektif

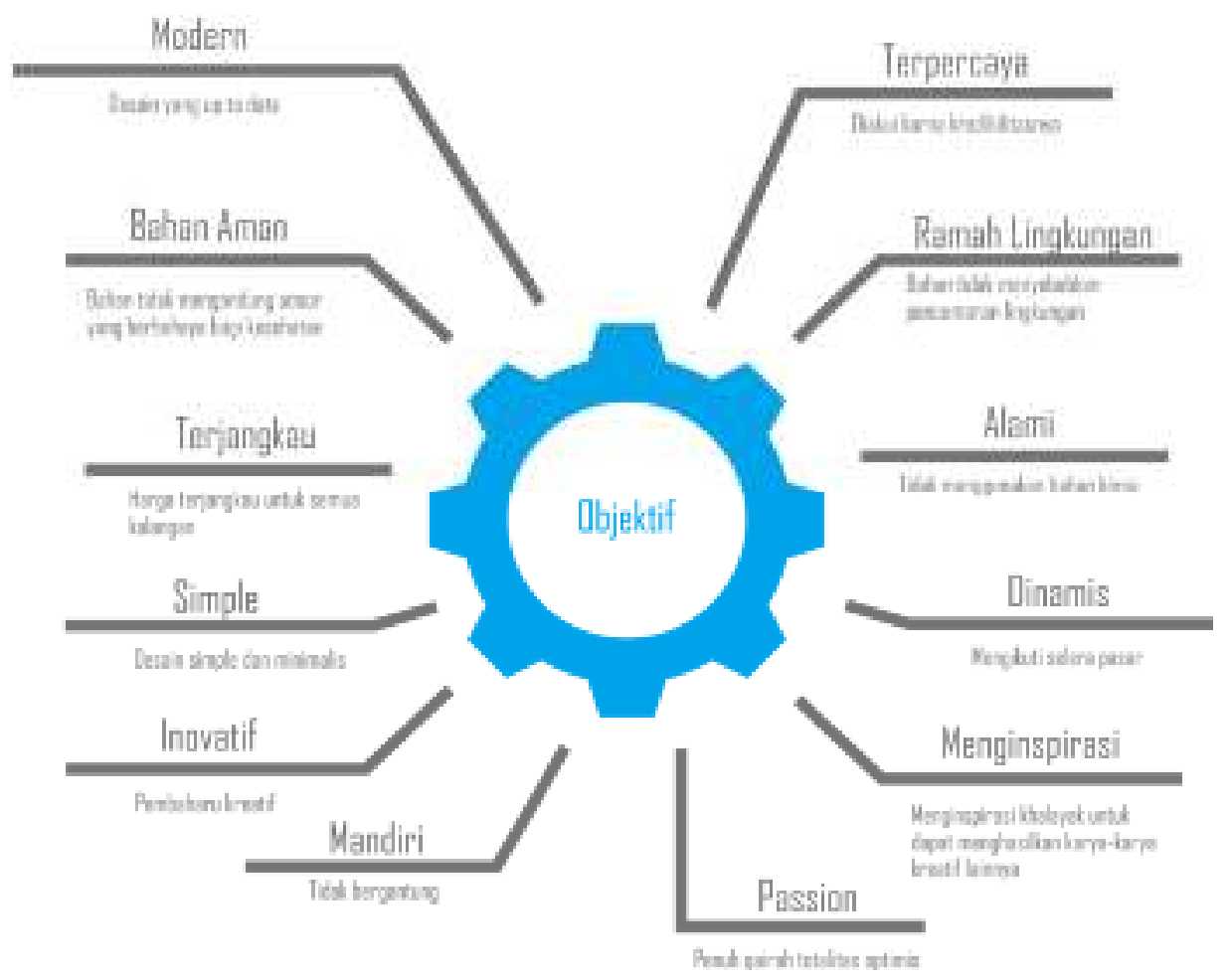

Gambar 7. Brainstorming yang bersifat Objektif 


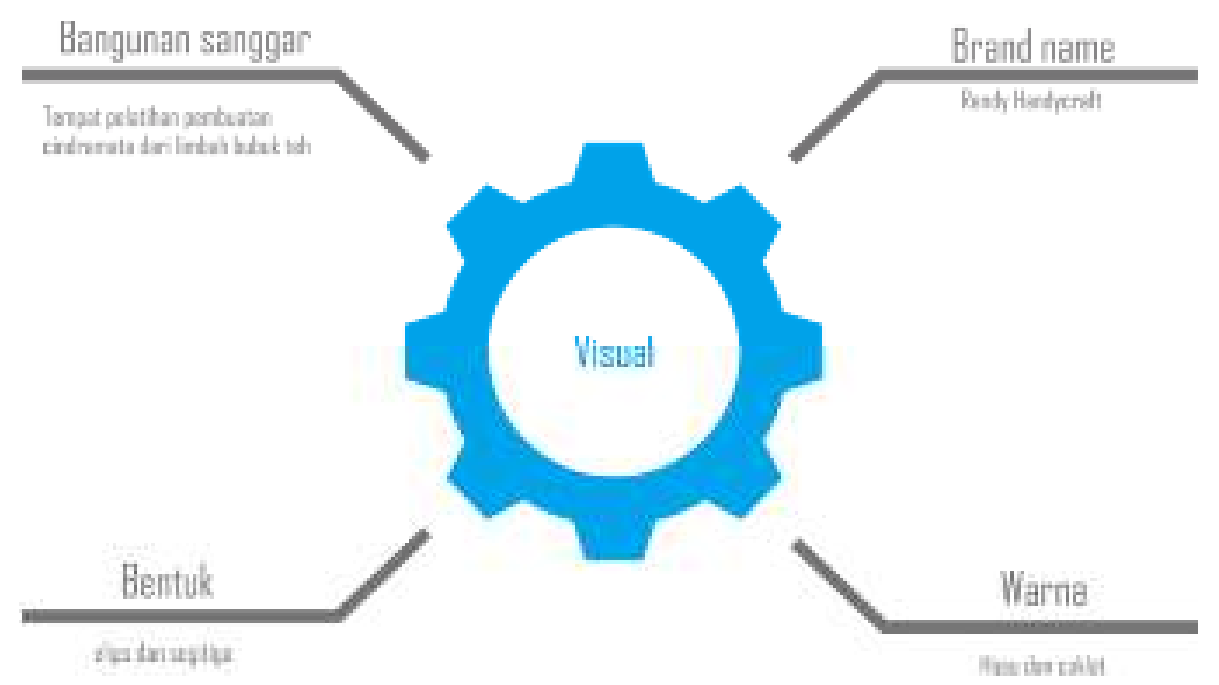

Gambar 8. Brainstorming yang bersifat Visual

c. Logo

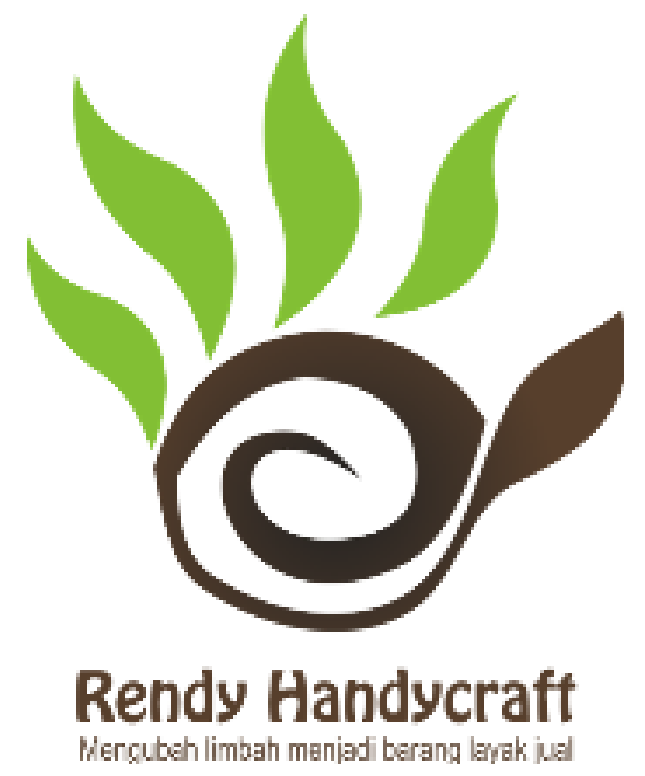

Gambar 9. Final Logo Rendy Handycraft

\section{d. Filosopi Logo}

Bentuk tangan yang mewakili kata handycraft juga memiliki makna 5 jari mewakili 5 unsur teh yang diolah menjadi kerajinan, yaitu debu teh, ampas daun teh, daun teh, ampas batang teh, dan batang teh. 5 jari juga dapat dimaknai dengan sekumpulan orang-orang kreatif yang mengolah limbah bubuk teh di dalam sanggar. Bentuk melingkar di telapak tangan memiliki makna recycle yang mengolah limbah menjadi barang yang memiliki nilai estetis dan daya jual. Bentuk keseluruhan dari logo juga mencitrakan cangkir teh dan asap. 


\section{e. Typeface}

Sama halnya dengan warna logo, penggunaan huruf pada aplikasi logo Rendy Handycraft adalah bagian vital dari keseluruhan logo dan harus selalu digunakan sesuai dengan peraturan yang terdapat di dalam buku ini tanpa pengecualian untuk menjaga konsistensi dan kesinambungan citra. Huruf yang digunakan pada dokumen resmi dan materi aplikasi adalah Hobo Std.

\section{HObO Std ABCDEFGHIJKLMNOPQRSTUUWXYZ abcdefghijklmnopqrstuvwxyz 1234567890$$
\text { +_*\%\$@@\&()<>!? }
$$ \\ Gambar 10. Font Hobo Std}

\section{f. Stationery}

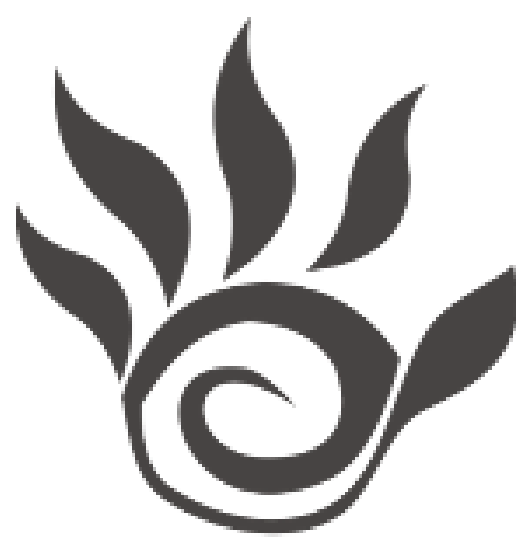

\section{Rendy Handycraft}

Menqubah imtah meriad berang lark usl

\section{Gambar 11. Stempel}

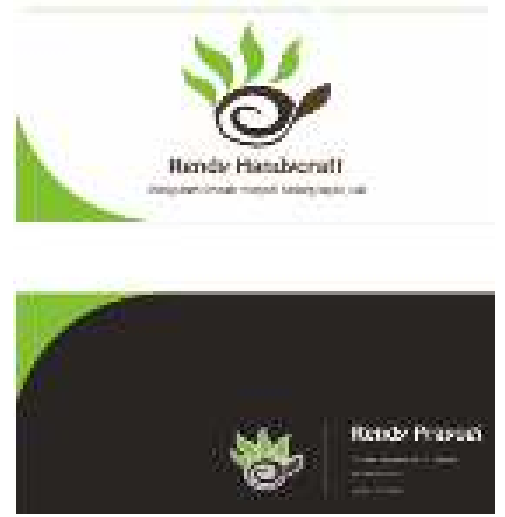

Gambar 13. Kartu Nama

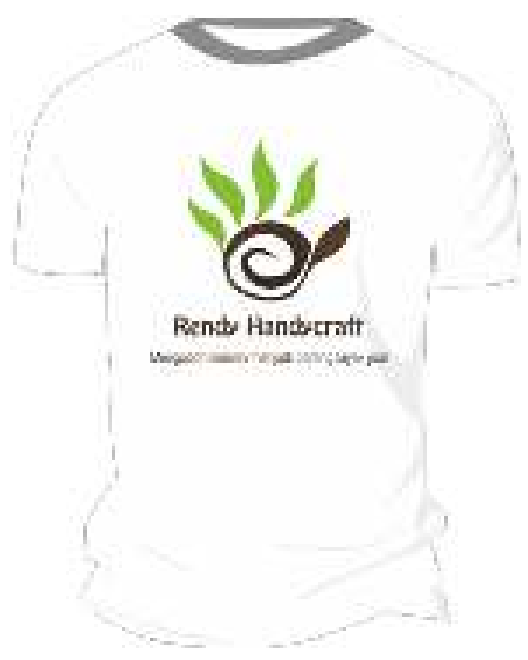

Gambar 12. Kaos

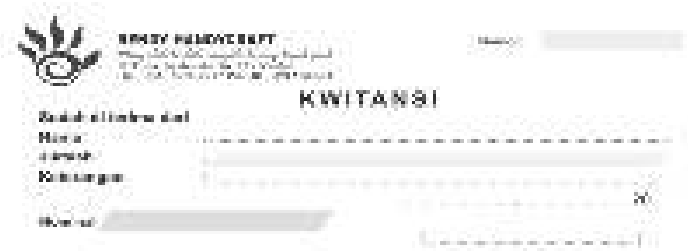

Gambar 14. Kwitansi 


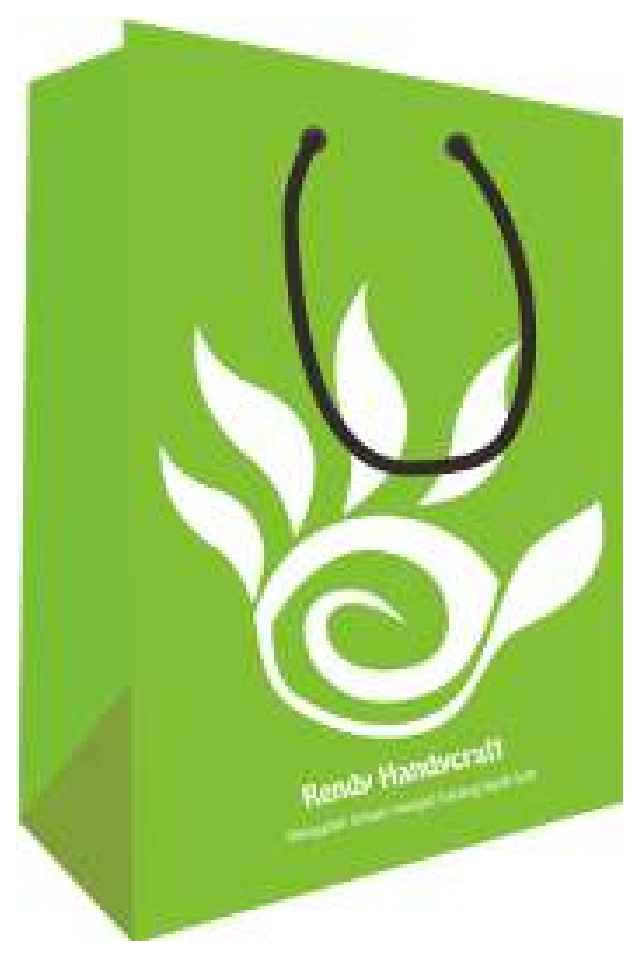

Gambar 15. Paper Bag

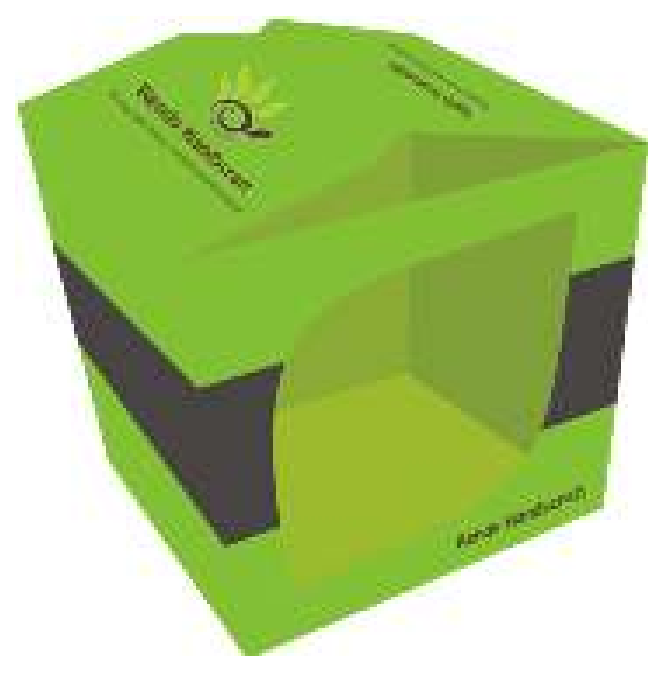

Gambar 16. Kemasan

\section{KESIMPULAN}

Proses perancangan brand identity ini melalui beberapa tahapan kreatif mulai dari pengumpulan data visual dan data verbal, yang dilanjutkan dengan analisis data kedalam bentuk mind mapping. Mind mapping tersebut kemudian dijadikan sumber dalam pencarian ide bentuk visual logo dengan membuat sketsa alternatif logo. Sketsa alternatif tersebut melahirkan beberapa wujud visual seperti bentuk daun teh, bentuk cangkir teh, bentuk kantung teh celup, bentuk visual produk, serta bentuk-bentuk lain yang berkaitan dengan Produk Rendy Handycraft. Alternatif-alternatif tersebut yang kemudian menjadi pilihan bagi owner untuk dijadikan satu logo komperhensif yang menjadi final desain. Selanjutnya alternatif yang terpilih akan dibuatkan dalam bentuk digital serta diberi warna sesuai dengan pilihan dari owner juga.

Perancangan ini menghasilkan brand identity sesuai dengan karakter Rendy Handycraft dan media aplikasinya. Media aplikasi meliputi kartu nama, kwitansi, stempel, kaos, kemeja karyawan, neon box, gantungan kunci, paper bag serta kemasan. Perancangan ini didesain dengan warna dominan hijau dan coklat. 


\section{DAFTAR PUSTAKA}

[1] Athika Dwi Wiji Utami. 2016. Perancangan Desain Logo LBH Sandhi Wafa \& Parners Counselor \& Attorneys At Law. Jurnal Ilmu Komputer dan DKV: Universitas Nahdatul Ulama Sidoarjo.

[2] Gelder, S.V. 2005. Global brand strategy. London: Kogan Page.

[3] Julita Rosella. 2013. Perancangan Logo \& Corporate Identity Hotel Gowin Bali. Jurnal DKV adiwarna: Universitas Kristen Petra.

[4] Philip Kotler. 2002. Manajemen Pemasaran, Edisi Millenium, Jilid 2, PT Prenhallindo, Jakarta

[5] Schultz,D.E.\& Bames, B.E. 1999. Strategic Brand communication Campaigns. Illionis: NTC Business Books.

[6] Suharto.Ign. 2011. Limbah Kimia dalam Pencemaran Air dan Udara. Yogyakarta : CV. Andi Offset. 